\title{
A genetic probe for identification of the turbot aquareovirus in infected cell cultures
}

\author{
Blanca Lupiani ${ }^{1}$, Kothandaraman Subramanian ${ }^{1}$, Frank M. Hetrick ${ }^{2}$, \\ Siba K. Samal ${ }^{1, *}$ \\ ${ }^{1}$ College of Veterinary Medicine, University of Maryland, College Park, Maryland 20742, USA \\ ${ }^{2}$ Maryland Institute for Agriculture and Natural Resources, University of Maryland, College Park, Maryland 20742, USA
}

\begin{abstract}
A nucleic acid hybridization assay has been developed that can detect small amounts of the turbot aquareovirus (TRV) in infected cells. Complementary DNAs were synthesized from the dsRNA genome segments of TRV and used to generate a large number of recombinant plasmids. Plasmids corresponding to genomic segments 1 through 8 were identified by Northern blot analysis. A randomly selected clone, Clone 66 , hybridizing to genome Segment 8 , showed high specificity hybridizing only RNA from TRV, and not with the RNAs of 4 other aquareoviruses, or with RNA extracted from infectious pancreatic necrosis virus (IPNV), infectious hematopoietic necrosis virus (IHNV) or with uninfected cells. A ${ }^{32} \mathrm{P}$-labeled probe was able to detect as little as $50 \mathrm{ng}$ of TRV purified virus dsRNA. Time course experiments indicated that TRV RNA can be detected in infected cells $96 \mathrm{~h}$ post-inoculation, a time when cytopathic effect is still not evident. These results indicate that the dot blot assay described here could be used as an effective diagnostic tool for the detection of TRV infections.
\end{abstract}

\section{INTRODUCTION}

Over the last 15 years, an increasing number of viruses with characteristics of the family Reoviridae have been isolated from aquatic animals, including crustacea, shellfish and fish from different geographic areas and environments (Hetrick et al. 1992). These viruses produce syncytia as a typical cytopathic effect (CPE) in susceptible fish cell lines. The virions are 70 to $75 \mathrm{~nm}$ in diameter and consist of a double-layered capsid containing a genome composed of 11 segments of doublestranded RNA (ds RNA). These viruses share some characteristics with the genera Rotavirus and Orthoreovirus but based on their host range, optimal growth temperature, RNA electrophoretic pattern, RNA-RNA hybridization studies and serological tests, they have been placed in the new genus Aquareovirus in the family Reoviridae (Francki et al. 1991).

Although most of these viruses were isolated during routine examination of apparently healthy fish (Meyers 1979, Winton et al. 1981, 1989, Ahne \& Kölbl 1987,

\footnotetext{
- Addressee for correspondence
}

Samal et al. 1991), some of them were isolated from fish suffering a mixed bacterial and viral infection (Lupiani et al. 1989, Baya et al. 1990), or from fish populations undergoing chronic or large mortalities (Plumb et al. 1979, Amend et al. 1984, Chen \& Jiang 1984, Hsu et al. 1989, Marshall et al. 1990, Varner \& Lewis 1991, Jiang et al. 1991). In 1987, an aquareovirus (TRV) was isolated from cultured turbot during a disease outbreak in northwest Spain (Lupiani et al. 1989). During the outbreak, there was a continuous but low mortality, with a cumulative loss of $4 \%$ of the affected population. A bacterium of the genus Vibrio was isolated from the same fish. Treatment of the affected fish with an antibiotic to which the bacterium was sensitive only temporarily suppressed mortality which suggested a possible role of TRV in the development of the disease.

Since vaccines to prevent aquareovirus infections are not available at this time, the best control measure is to prevent the introduction of these viruses into aquaculture facilities. Currently, detection of aquareoviruses requires virus isolation and serological identification. Since aquareoviruses grow relatively slowly $(10$ to $14 \mathrm{~d}$ ) there is a need for a more rapid detection method. 
Nucleic acid hybridization techniques have been employed for the identification of many human and animal viruses (Kulski \& Norval 1985, Viscidi \& Yolken 1987. Rimstad et al. 1990). We describe here the development of such an assay for the detection of TRV infections in fish. This involved the synthesis of cDNA clones of the TRV strain of aquareovirus so that the probe can be produced in large quantities at reasonably low cost.

\section{MATERIALS AND METHODS}

Viruses and cells. Five strains of aquareovirus were used: TRV, isolated from turbot Scophthalmus maximus in Spain (Lupiani et al, 1989), SBR, isolated from striped bass Morone saxatilis collected in the Chesapeake Bay, USA (Baya et al. 1990); SRV isolated from smelt Osmerus mordax in Canada (Marshall et al. 1990); and HBR and ASV isolated from the sex products of different populations of Atlantic salmon Salmo salar in the USA and Canada, respectively (Samal et al. 1991). Two other fish viruses, infectious pancreatic necrosis virus (IPNV), a birnavirus, and infectious hematopoietic necrosis virus (IHNV), a rhabdovirus, were used as controls to determine the specificity of the probes. All viruses were propagated at $15^{\circ} \mathrm{C}$ in chinook salmon embryo cells (CHSE-214) grown in minimum essential medium (MEM) supplemented with $10 \%$ fetal bovine serum, $100 \mathrm{U} \mathrm{ml}^{-1}$ penicillin, $100 \mu \mathrm{g}$ $\mathrm{ml}^{-1}$ streptomycin and $2.5 \mu \mathrm{g} \mathrm{ml}^{-1}$ fungizone

Virus purification and extraction of doublestranded RNA. Virus particles were purified as previously described (Ramig et al. 1977, Samal et al. 1990) using PEG precipitation, freon extraction and sucrose gradient sedimentation. Purified virus was resuspended in $1 \mathrm{X} \mathrm{SSC}$ and stored at $4{ }^{\circ} \mathrm{C}$ until used. The dsRNAs were extracted from purified virus with phenol: chloroform $(1: 1)$, chloroform and ether, and precipitated with ethanol and sodium acetate.

Cloning of the genomic segments for preparation of diagnostic probe. The method of Cashdollar et al. (1982) was used with slight modifications for cloning TRV dsRNA. Briefly, approximately $5 \mu \mathrm{g}$ of dsRNA was denatured in $10 \mathrm{mM}$ methylmercury hydroxide at room temperature for $10 \mathrm{~min}$. Excess methylmercury hydroxide was quenched by the addition of $140 \mathrm{mM}$ $\beta$-mercaptoethanol. Random hexamers (Pharmacia, Piscataway, NJ, USA) were used to prime the first strand reaction. Denatured viral RNA (5 $\mu \mathrm{g})$ and random primers $(5 \mu \mathrm{g})$ were mixed in a reaction buffer (50 mM Tris $\mathrm{HCl} \mathrm{pH} 8.3,10 \mathrm{mM} \mathrm{MgCl}, 10 \mathrm{mM}$ dithiothreitol, $4 \mathrm{mM}$ sodiumpyrophosphate, $1.25 \mathrm{mM}$ of each of the deoxynucleotide triphosphates) and $100 \mathrm{U}$ of avian myeloblastosis virus reverse transcrip- tase (AMV) was added and the mixture incubated for $1 \mathrm{~h}$ at $42^{\circ} \mathrm{C}$. The reaction products were extracted with phenol : chloroform $(1: 1)$ and precipitated with ethanol and ammonium acetate. Second-strand synthesis was carried out as described by Gubler \& Hoffman (1983) using RNase $\mathrm{H}$ and Escherichia coli DNA polymerase I. The double-stranded DNA was blunt-ended with $\mathrm{T} 4$ DNA polymerase, and ECoRI linkers (Promega Biotech) were ligated to the blunt-ended CDNA with T4 DNA ligase (Sambrook et al. 1989). A sepharose CL4B column (Pharmacia) was used to separate EcoRI-ended cDNA from free linkers. The cDNA was then phosphorylated using T4 polynucleotide kinase and ligated to EcoRI-digested plasmid, pUC19. This preparation was used to transform E. coli JM 109 cells (Hanahan 1985) and the transformed mixture was plated on bacterial culture plates containing ampicillin, IPTG, and $X$-Gal. Bacteria containing recombinant plasmids were identified by ampicilin resistance and white colonies. Plasmids were isolated from randomly selected colonies by the method described by Birnboim \& Doly (1979). Plasmids were digested with EcoRI and examined by agarose gel electrophoresis to confirm the presence and determine the size of the inserts.

Northern blot hybridization. Northern blot hybridization (Alwine et al. 1979) was used to determine the specificity of cDNA inserts for each of the 11 genome segments of TRV. Briefly, probes were prepared by excising and extracting cDNA inserts from agarose and radiolabeling by random-priming (Feinberg \& Vogelstein 1983). The TRV genomic dsRNA segments were electrophoresed in polyacrylamide gels, transferred to Gene Screen Plus membrane by electrobloting and hybridized with radiolabeled cDNA probes. The dsRNA genomic segment reacting with each probe was determined by comparison with the 11 TRV dsRNA segments that were $3^{\prime}$-end-labeled using [5'$\left.{ }^{32} \mathrm{P}\right] \mathrm{pCp}$ (England \& Uhlenbeck 1978). Prehybridization and hybridization was carried out at $42^{\circ} \mathrm{C}$ as described by Bodkin \& Knudson (1985).

Isolation of total RNA from virus-infected cells. Confluent monolayers of CHSE-214 cells grown in $25 \mathrm{~cm}^{2}$ cell culture flasks were infected with the 5 aquareovirus strains, IPNV and IHNV at a multiplicity of infection (MOI) of 0.01 and 0.1 . After $1 \mathrm{~h}$ of adsorption, the monolayers were washed with PBS and maintenance medium (MEM plus $2 \%$ FBS) was added. When CPE was evident, the cells were removed from the culture flask and resuspended in $1 \mathrm{ml}$ of TNE buffer $(10 \mathrm{mM}$ Tris $\mathrm{HCl} \mathrm{pH}$ 7.4, $1 \mathrm{mM}$ EDTA, $150 \mathrm{mM}$ $\mathrm{NaCl}$ ). The suspension was brought to $0.5 \%$ Nonidet P-40 and kept on ice for 10 min. Nuclei were pelleted at $14000 \times g$ for $5 \mathrm{~min}$ and the supernatant was transferred to a new tube. SDS $10.1 \%$ final concentration) 
and proteinase $\mathrm{K}\left(200 \mu \mathrm{g} \mathrm{m} \mathrm{m}^{-1}\right)$ were added to the supernatant and the solution was incubated at $45^{\circ} \mathrm{C}$ for $1 \mathrm{~h}$. The mixture was extracted first with phenol: chloroform and then with chloroform alone. Total RNA was precipitated with sodium acetate and ethanol and the pellet was resuspended in TE buffer $(10 \mathrm{mM}$ Tris $\mathrm{pH} 7.4,1 \mathrm{mM}$ EDTA)

Time course experiments. Time course experiments were conducted to determine the minimum incubation period required for production of detectable levels of TRV RNA. Replicate monolayers of CHSE-214 cells were infected with TRV at MOIs of 0.01 and 0.1. After $1 \mathrm{~h}$, the monolayers were washed with PBS to remove unadsorbed virus and maintenance medium was added. At various times post-infection, cells were removed and RNAs extracted for blotting as described above. RNAs from mock-infected cells and the heterologous viruses, IPNV and IHNV, were used as negative controls.

Dot-blot hybridization of dsRNA. RNA extracted from infected cell cultures was denatured by the addition of $10 \mathrm{mM}$ methylmercury hydroxide and then spotted onto a Gene Screen Plus membrane using a 96-well filtration unit. Membranes containing viral RNA were baked at $80^{\circ} \mathrm{C}$ for $30 \mathrm{~min}$ and then soaked in a prehybridization solution for $2 \mathrm{~h}$ at $42^{\circ} \mathrm{C}$ using Hybrisol I (Oncor) (50\% formamide). Labeled cDNA probes were denatured by heating at $100^{\circ} \mathrm{C}$ for $5 \mathrm{~min}$ and added to the prehybridization mixture. After overnight hybridization at $42{ }^{\circ} \mathrm{C}$, the membranes were washed at room temperature in $1 \times$ SSC containing $0.1 \%$ SDS and then at $58{ }^{\circ} \mathrm{C}$ in $0.1 \times$ SSC containing $0.1 \%$ SDS for $1 \mathrm{~h}$ before autoradiography.

\section{RESULTS}

\section{Synthesis of TRV virus cDNA clones}

More than 1000 ampicillinresistant colonies were obtained from the cloning procedure used. All white colonies tested by enzymatic digestion analysis contained plasmids with cDNA inserts. The size of the different inserts was determined on $1 \%$ agarose gels and ranged from 250 to 1800 nucleotides. Recombinant plasmids were identified by hybridization of radiolabeled inserts to a blot of TRV virus dsRNA segments separated by SDS-PAGE. No clones corresponding to Segments 9, 10 and 11 were detected, although many clones corresponding to the other segments were found. Among these, Clone 8 reacted with Segment 2, Clone 19 with Segment 3, Clone 58 with both Segments 2 and 3, Clone 66 with Segment 8, and Clone 67 with Segment 6 (Fig. 1).

\section{Specificity of probes from TRV aquareovirus cDNA clones}

The specificity of one randomly selected clone, Clone 66 corresponding to Segment 8, was examined by hybridization to dot blots of dsRNA extracted from 5 purified aquareovirus strains (TRV, SBR, HBR, ASV and SRV) as well as to dot blots of total RNA extracted

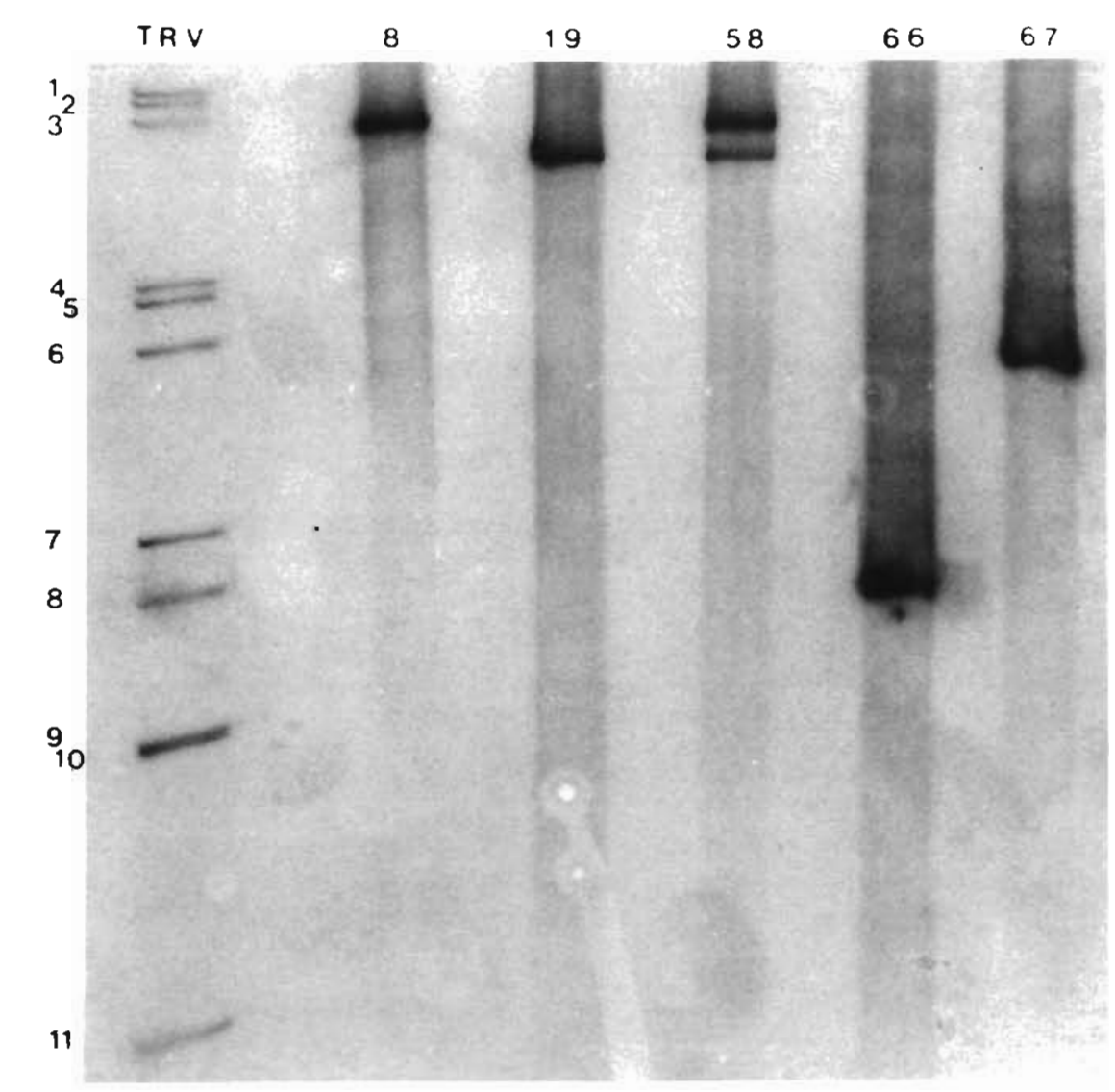

Fig. 1. Identification of TRV CDNA clones by Northern blot analysis. TRV virus dsRNA was electrophoresed in a $6 \%$ SDS-PAGE gel and the RNA was electrophoretically transferred to a Gene Screen Plus membrane. cDNA inserts (numbered lanes) were labeled with ${ }^{32} \mathrm{P}$ by random-priming and each insert was hybridized with a strip of the membrane containing all 11 dsRNA segments. The positions of the 11 genome segments are shown in the lane labeled TRV 


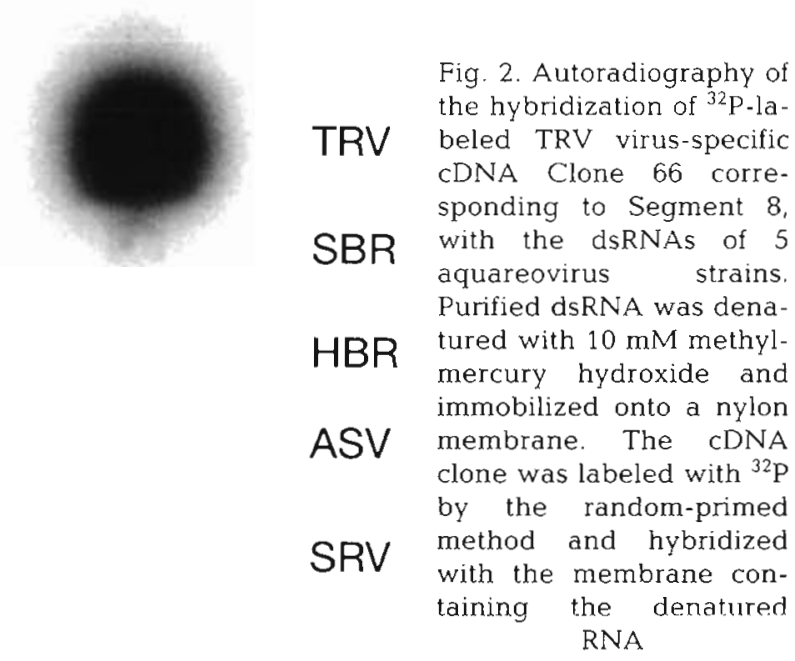

from ceil cultures infected with the 5 strains of aquareovirus, or with IPNV, IHNV, and mock-infected cells. Clone 66 hybridized well with dsRNA extracted from purified TRV (Fig. 2) and with the RNA extracted from TRV-infected cells (Fig. 3), but it did not hybridize with the RNAs of the other aquareoviruses, or with IPNV, IHNV or mock-infected cells.

\section{Sensitivity of the Clone 66 probe}

Time-course experiments demonstrated that the Clone 66 probe could detect the presence of TRV RNA in infected cells as early as $96 \mathrm{~h}$ post-infection when CPE was still not evident (Fig. 4). The sensitivity of the CDNA probe made from Clone 66 was determined by hybridization with different amounts of dsRNA extracted from purified TRV. Clone 66 detected as little as $50 \mathrm{ng}$ of genomic viral RNA in dot blot hybridization studies (Fig. 5).

\section{DISCUSSION}

In the present study, we have described the cloning of cDNA inserts made from the dsRNAgenome segments of TRV aquareovirus. A large number of recombinant plasmids were obtained using the cloning procedure described. Plasmids corresponding to genomic Segments 1 through 8 were identified by Northern blot analysis. No recombinant plasmids corresponding to Segments 9 to 11 were detected, probably because they were lost during the RNA purification process due to their small size. The size of the different CDNA inserts ranged from 250 to 1800 nucleotides.

Clone 66, hybridizing to the TRV genome Segment 8, was randomly selected and its specificity and sensitivity were tested for use as a potential probe for diag-
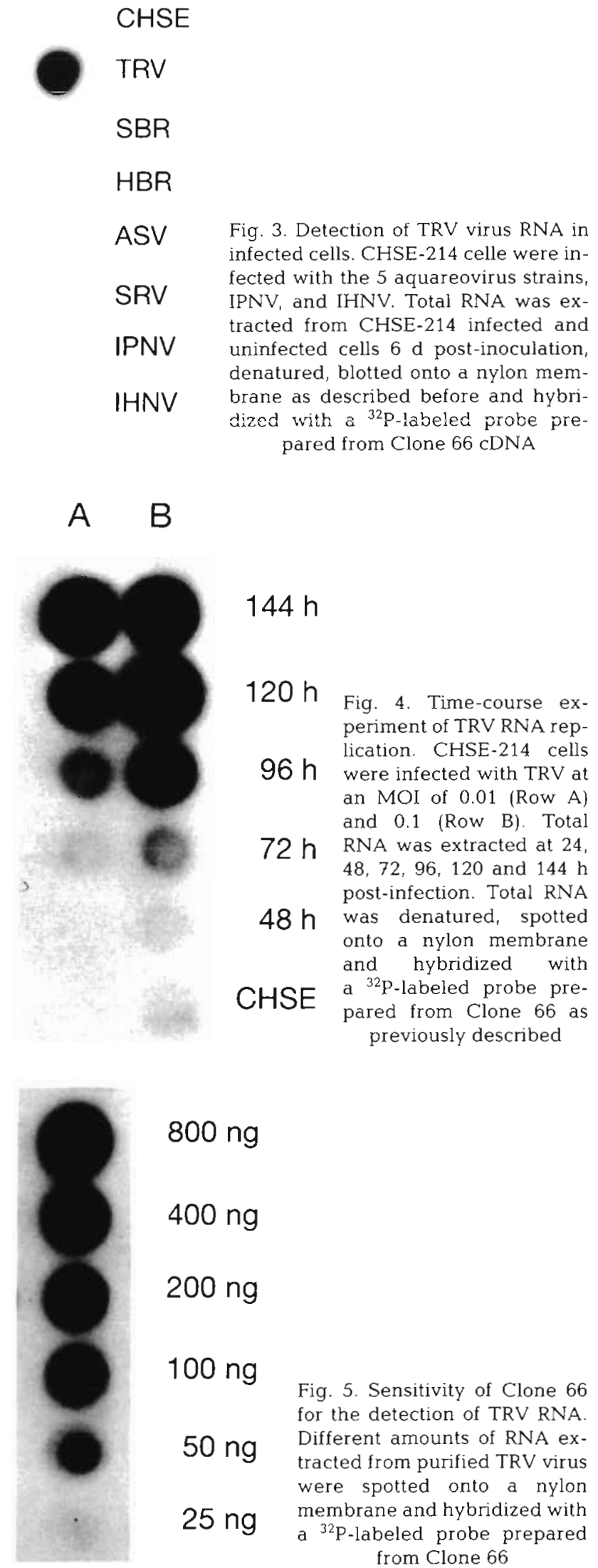

$800 \mathrm{ng}$

$400 \mathrm{ng}$

$200 \mathrm{ng}$

$100 \mathrm{ng}$

Fig. 5. Sensitivity of Clone 66 for the detection of TRV RNA

$50 \mathrm{ng}$ Different amounts of RNA extracted from purified TRV virus were spotted onto a nylon membrane and hybridized with a ${ }^{32}$ P-labeled probe prepared from Clone 66 
nostic purposes. Clone 66 was shown to be highly specific, hybridizing only to RNA from TRV, and not with the RNAs of other aquareovirus strains tested (SBR, HBR, ASV and SRV), or with IPNV, IHNV or uninfected cells. These results indicate that the dot blot assay described here could be used as an effective diagnostic tool for the detection of TRV infections. Experiments are in progress to determine the specificity of the probe in tissue samples of TRV-infected fish and to study the pathogenesis of TRV infections. The specificity of the TRV CDNA probe confirms our previous observations that the TRV isolate is genetically different from other North American aquareovirus isolates (Samal et al. 1991). The specificity of the probe also provides an easy way to determine the presence of other aquareovirus strains genetically similar to TRV and hence to study the genetic relatedness among different aquareovirus isolates.

The cDNA probe was able to detect $50 \mathrm{ng}$ of TRV dsRNA. The sensitivity reported for rotavirus probes in this type of assays is in the range of 0.5 to $5 \mathrm{ng}$ of RNA (Dimitrov et al. 1985, Eiden \& Yolken 1987). We are attempting to improve the sensitivity of the cDNA probe by increasing the specific activity of the cDNA and by using highly specific RNA probes as described by Kreig \& Melton (1984). Our cDNA probe should also be useful in determining the distribution of TRV in natural fish populations and for studying the structure and function of the TRV genes.

Acknowledgements. This work was supported by a grant from the Maryland Agricultural Experiment Station. Approved as Scientific Article No. A6361, Contribution No. 8545 of the Maryland Agricultural Experiment Station. B.L. is the recipient of a research fellowship from the Fulbright Commission/MEC of Spain

\section{LITERATURE CITED}

Ahne, W., Kölbl, O. (1987). Occurrence of reoviruses in European cyprinid fishes (Tinca tinca Lin.; Leuciscus cephalus Lin.). J. appl. Ichthyol. 3: 139-141

Alwine, J. C., Kemp, D. J., Parker, B. A., Reiser, J. (1979). Detection of specific RNAs or specific fragments of DNA by fractionation in gels and transfer to diazobenzyloxymethyl paper. Meth. Enzymol. 68: 220-242

Amend, D. F., McDowell, T., Hedrick, R. P. (1984). Characteristics of a previously unidentified virus from channel catfisch (Ictalurus punctatus). Can. J. Fish. Aquat. Sci. $41: 807-811$

Baya, A., Toranzo, A. E., Nuñez, S., Barja, J. L., Hetrick, F. M. (1990). Association of a Moraxella sp. and a reo-like virus with mortalities of striped bass, Morone saxatilis. In: Perkins, F. O., Cheng, T. C. (eds.) Pathology in marine science. Academic Press, New York, p. 90-99

Birnboim, H. C., Doly, J. (1979). A rapid alkaline extraction procedure for screening recombinant plasmid DNA. Nucl. Acid Res. 1: 1513-1523

Bodkin, D. K., Knudson, D. L. (1985). Sequence relatedness of
Palyam viruses to cognates of Palyam serogroup viruses by RNA-RNA blot hybridization. Virology 143: 55-62

Cashdollar, L. W., Esparza, J., Hudson, G. R., Patrick, C., Lee, W. K., Joklik, W. K. (1982). Cloning the double-stranded RNA genes of reovirus: sequence of the cloned S2 gene. Proc. Natl. Acad. Sci. 79: 7644-7648

Chen, Y., Jiang, Y. (1984). Morphological and physio-chemical characterization of the hemorrhagic virus of grass carp. Kexue Tongboa. 29: 832-835

Dimitrov, D. H., Graham, D. Y., Estes, M. K. (1985). Detection of rotavirus by nucleic acid hybridization with cloned DNA of simian rotavirus SA11 genes. J. infect. Dis. 153: 293-300

Eiden, J., Sato, S., Yolken, R. (1987). Specificity of dot blot hybridization assay in the presence of rRNA for detection of rotaviruses in clinical specimens. J. clin. Microbiol. 25: $1809-1811$

England, T. E., Uhlenbek, O. C. (1978) . 3'terminal labeling of RNA with T4 RNA ligase. Nature 275: 560-561

Feinberg, A. F., Vogelstein, B. (1983). A technique for radiolabeling DNA restriction endonuclease fragments to high specific activity. Anal Biochem. 132: 6-13

Francki, R. I. B., Fauquet, C. M., Knudson, D. L., Brown, F. (eds.) (1991). Classification and nomenclature of viruses. Arch. Virol. Suplementum 2: 1-450

Gubler, U., Hoffman, B. J. (1983). A simple and very efficient method for generating cDNA libraries. Gene 25: 263-269

Hanahan, D. (1985). Techniques for transformation of $E$. coli. In: Glover, D. (ed.) DNA cloning, a practical approach, Vol. 1. IRL Press, Oxford.p. 109-135

Hetrick, F. M., Samal, S. K., Lupiani, B., Dopazo, C. P., Subramazian, K. Mohanty, S. B. (1992). Members of the family Reoviridae found in aquatic animals. Proceedings of the OJI International Symposium on Salmonid Diseases. Hokkaido University Press, Sapporo, p. 33-40

Hsu, Y. L., Chen, B. S., Wun, J. L. (1989). Characteristics of a new reo-like virus isolated from landlocked salmon (Oncorhynchus masou Brevoort). Fish Pathol. 24: 37-45

Jiang, Y., Ahne, W., Li, Y., Ogawa, M. (1991). Isolation of an aquareovirus from common carp (Cyprinus carpio) in the P.R. China. Proceedings Second International Symposium on Viruses of Lower Vertebrates. Oregon State University Press, Corvallis, p. 287-292

Kreig, P. A., Melton, D. A. (1984). Functional mRNAs are produced by SP6 in vitro transcription of cloned cDNAs. Nuc. Acid Res. 12: 7057-7070

Kulski, J. K., Norval, M. (1985). Nucleic acid probes in diagnosis of viral diseases of man. Arch. Virol. 83: 3-15

Lupiani, B., Dopazo, C. P., Ledo, A., Fouz, B., Barja, J. L., Hetrick, F. M., Toranzo, A. E. (1989). New syndrome of mixed bacterial and viral etiology in cultured turbot, Scophthalmus maximus. J. aquat. anim. Health 1: 197-204

Marshall, S. H., Samal, S. K., McPhillips, T. H., Moore, A. R., Hetrick, F. M. (1990). Isolation of a rotavirus from smelt, Osmerus mordax (Mitchell). J. Fish Dis. 13: 87-91

Meyers, T. R. (1979). A reo-like virus isolated from juvenile American oyster (Crassostrea virginica). J. gen. Virol. 43: 203-212

Plumb, J. A., Bowser, P. R., Grizzle, J. M., Mitchell, A. J. (1979). Fish viruses: a double-stranded RNA icosahedral virus from a North American cyprinid. J. Fish. Res. Bd Can. 36: 1390-1394

Ramig, R. F., Cross, R. K., Fields, B. N. (1977). Genome of RNAs and polypeptides of reovirus serotypes 1,2 and 3 . Virology 22: 726-733

Rimstad, E., Krona, R., Hornes, E., Olsvik, O., Hyllseth, B. (1990). Detection of infectious pancreatic necrosis virus 
(IPNV) RNA by hybridization with an oligonucleotide DNA probe. Vet. Microbiol. 23: 211-219

Samal, S. K., Dopazo, C. P., McPhillips, T H., Baya, A., Mohanty, S. B., Hetrick, F. M. (1990). Molecular characterization of Rotavirus-like virus isolated from striped bass (Morone saxatilis). J. Virol. 64: 5235-5240

Samal, S. K., Dopazo, C. P., Subramanian, K., Lupiani, B., Mohanty, S. B., Hetrick, F. M. (1991). Heterogeneity in the genome RNAs and polypeptides of five members of a novel group of rota-like viruses isolated from aquatic animals. J. gen. Virol. 72: 181-184

Sambrook, H. C., Fritsch, E. F., Maniatis, T. (1989). Molecular cloning: a laboratory manual. Cold Spring Harbor Laboratory, Cold Spring Harbor, NY

Editorial responsibility: Managing Editor
Varner, P. W., Lewis, D. H. (1991). Characterization of a virus associated with head and lateral line erosion syndrome in marine fish. J. aquat. anim. Health. 3: 198-205

Viscidi, R. P., Yolken, R. G. (1987). Advances in the use of nucleic acid probes in diagnosis of viral diseases of man. Arch. Virol. 97: 151-165

Winton, J. R., Arakawa, C. K., Lannan, C. N., Fryer, J. L. (1989). Isolation of a reovirus from coho salmon (Oncorhynchus kistch) in Oregon, USA. In: Ahne, W., Kurstak, E. (eds.) Viruses of lower vertebrates. SpringerVerlag, Berlin, p. 257-269

Winton, J. R., Lannan, C. N., Fryer, J. L., Kimura, T. (1981) Isolation of a new reovirus from chum salmon in Japan. Fish Pathol. 15: 155-162

Manuscript first received: October 28, 1992 Revised version accepted: February 23, 1993 